\title{
EFFECTIVE REPLACEMENT OF CEMENT BY CERAMIC WASTE IN CONCRETE FOR SUSTAINABLE DEVELOPMENT
}

\author{
A.J.Jeya Arthi \\ Assistant Professor, Civil Engineering, Rajalakshmi Engineering College, Chennai, India
}

\begin{abstract}
In the contemporary existences the ceramic waste consumption have been urbanized a huge volume. Almost $15 \%-30 \%$ ceramic production goes as discarded. These wastes pose a challenging extent in the existing society, and it requires a proper form of management in order to accomplish the sustainable development. It is utmost important to develop a sustainable concrete from ceramic wastes. The ceramic waste is economical and it also improves the strength characteristics moreover a harmless clearance of waste material is protecting from contamination. In this investigation the ordinary Portland cement has been partially substituted as ceramic waste powder in the range of 0\%, 15\%, 30\%, 35\%, 40\% and 45\% by weight of M 20 grade of concrete. Recycle of this generous waste has improvement in cost-effective and eco-friendly, and decrease in the amount of typical spaces employed as refuse dumps. Hence in this study the ordinary Portland cement is been replaced by ceramic waste and the test on compression strength, flexural strength, split tensile strength of conventional concrete and ceramic replaced concrete are compared and the results is been tabulated.
\end{abstract}

Keywords: Ceramic Waste, Sustainable Development, Economical, Eco- Friendly

\section{GENERAL}

The ceramic waste management has become one of the foremost ecofriendly problems in many cities. It has been a persistent problem in India since for a decade due to consecutively out of disposal sites to accomplish the massive volume of waste produced. Many people believe that sustainability takes a break during construction activities. In recent years, initiatives have been investigated on a global and national level to control and regulate waste management. The development of concrete technology can minimize the intake of natural assets. The consumption of the additional materials offers reduction of the cost, energy savings, possibly larger products, and fewer exposures in the surroundings. The additional cementing material has established the application in concrete production because of their prospective to replace a part of Portland cement in concrete. Hence, these constituents can be measured as eco-friendly cement alternatives. The manufacture of Indian ceramic is 100 Million ton per year. In the ceramic industry, $15 \%-30 \%$ surplus material produced from the total manufacture. The ceramic waste is not reused in any form at contemporary days. Nevertheless; the ceramic discarded is hard-wearing and highly impervious to organic, biochemical, and physical degradation forces.

The Ceramic productions are discarding the ash in any adjacent pit or unoccupied places, near their part even though warned zones have been noticeable for discarding. This tops to severe ecological and dust contamination and occupation of a massive zone of land, particularly after the residue become dry up so it is necessary to organize the Ceramic waste rapidly and use in the construction industry. The ceramic waste is heaping up; there is a density on ceramic industries to catch an explanation for its removal.
The demolition rubbishes give the determined quantity of debris global. Furthermore, ceramic ingredients, includes block walls, ceramic tiles and all other ceramic yields, subsidize the utmost proportion of rubbishes inside the demolition wastes. Excess ceramic constituents could develop a inexpensive but almost equal substitute to fly ash and other materials as additional binder in concrete. The ceramic industry often yields calcined soils that product from fiery elite-group clays which are universally recycled in the invention of red-clay ceramic products.

\section{ALTERNATE MATERIAL FOR CEMENT}

Cement is a general name for a material that binds other material together. The major ingredient is concrete, mortar and plaster. Since the raw materials used for the cement production is limited, the cost is high and the production causes $\mathrm{Co}_{2}$ emission (about $10 \%$ of world's $\mathrm{Co}_{2}$ emission) the invention of an alternative material is required. In order to reduce the demand and cost of cement, an alternative material shall be used to replace this by locally available material which possesses cementitious property.

\section{CERAMIC WASTE}

Around $15 \%-30 \%$ of ceramic industry goes as waste from the total production. The waste is not reused in any form at existing however; the ceramic waste is long-lasting, durable and highly impervious to biological, chemical, and physical degradation forces. Hence these scraps remain grinded finely to the size of cement and used as an alternative material for cement in construction industry. The ceramic waste material used for the investigation came from tiles and sanitary ware. 
Table 1.1: Chemical composition of ceramics

\begin{tabular}{|l|l|}
\hline Chemicals & Percentage\% \\
\hline $\mathrm{SiO}_{2}$ & 63.29 \\
\hline $\mathrm{Al}_{2} \mathrm{O}_{3}$ & 18.29 \\
\hline $\mathrm{Fe}_{2} \mathrm{O}_{3}$ & 4.32 \\
\hline $\mathrm{CaO}$ & 4.46 \\
\hline $\mathrm{MgO}$ & 0.72 \\
\hline $\mathrm{P}_{2} \mathrm{O}_{5}$ & 0.16 \\
\hline $\mathrm{K}_{2} \mathrm{O}$ & 2.75 \\
\hline $\mathrm{Na}_{2} \mathrm{O}$ & 0.75 \\
\hline
\end{tabular}

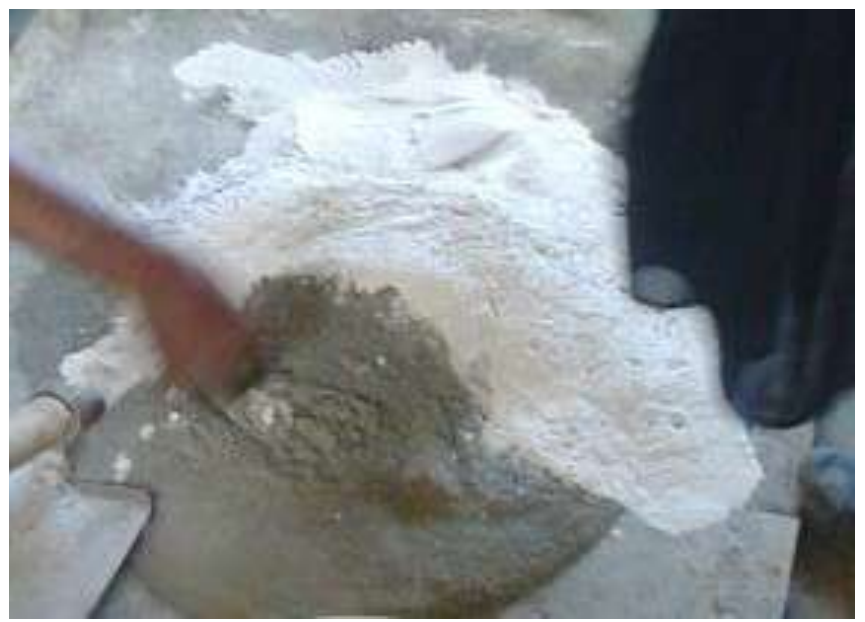

Fig 1.1 Ceramic Waste

\section{CERAMIC WASTEPOWDER AS AN}

\section{ALTERNATIVE MATERIAL FOR CEMENT}

In the industry about $15 \%-30 \%$ of production goes as waste. These wastes are not used for sale due to a variety of reasons and they are dumped away in nearby pits which results in environmental pollution. This study is conducted to know the effectiveness of ceramic waste powder as the partial replacement of cement in concrete with different proportion after investigating the properties of ceramic waste.
To study the effects of ceramic waste powder as cement in concrete, a series of tests on physical characteristics of the cement were conducted. For comparison purposes, similar tests on conventional concrete and concrete with ceramic waste powder as partial replacement of cement also performed.

\section{SCOPE AND OBJECTIVES}

1) To develop the solution for waste reduction by replacing ceramic waste powder instead of cement in concrete and also to protect the environment from a part of ceramic waste pollution.

2) The tests were conducted to investigate the probable of ceramic barren powder as cement in concrete.

3) Physical characteristics tests were performed on ceramic waste powder and the result were compared.

4) The objective of the project is to substitute the cement partially in the concrete by the ceramic waste powder with a percentage replacement ranging from $0 \%$ to $45 \%$ on the strength criteria of $\mathrm{M}_{20}$ concrete.

5) Compression test, split tensile test were performed on conventional concrete and the cement replaced concrete by ceramic waste powder and test results are compared.

6) The main objective is to utilize ceramic waste in a proper manner to protect the environment and to control carbon dioxide emission.

7) It reduces the land fill area and leachates etc.., and to bring the latest developments in concrete technology.

8) It is most important to create sustainable concrete from ceramic waste and to reduce the usage of cement and overall concrete price and to give good strength at low cost.

\section{TEST RESULTS}

\subsection{Experimental Procedure for Compression Test on Concrete Cubes}

The strength of concrete is varying due to the period of curing. So the variation of compressive strength due to the duration of curing is tested at 7 days, 21 days and 28days

Table 1.2: Compressive strength test results in N/mm

\begin{tabular}{|l|l|l|l|l|l|l|l|}
\hline No & Mix specifications & Control mix & A1 & A2 & A3 & A4 & A5 \\
\hline 1 & Proportion of Ceramic waste powder & $0 \%$ & $15 \%$ & $30 \%$ & $55 \%$ & $40 \%$ & $45 \%$ \\
\hline 2 & 7 DAYS & 21.1 & 20.85 & 20 & 19.65 & 18.36 & 18.10 \\
\hline 3 & 14 DAYS & 24.65 & 23.85 & 22.35 & 21.5 & 20 & 19.35 \\
\hline 4 & 28 DAYS & 26 & 25.32 & 24.90 & 23.43 & 20.83 & 19.50 \\
\hline
\end{tabular}

\subsection{Experimental Procedure of Rebound Hammer}

\section{for Determining the Compression Strength on}

\section{Concrete Cubes}

Rebound hammer test is done to find out the compressive strength of concrete by using rebound hammer as per IS 13311 (Part 2)- 1992.
Table 1.3: Compression strength test results by rebound hammer in $\mathrm{N} / \mathrm{mm}^{2}$

\begin{tabular}{|l|l|l|l|l|l|l|}
\hline \multirow{2}{*}{ Tested days } & \multicolumn{6}{|c|}{ Replacement proportion of ceramic waste } \\
\cline { 2 - 7 } & $0 \%$ & $15 \%$ & $30 \%$ & $35 \%$ & $40 \%$ & $45 \%$ \\
\hline 7 & 25 & 24 & 23.16 & 21.54 & 15 & 14.15 \\
\hline 28 & 30 & 28.99 & 27.50 & 23.5 & 18 & 16 \\
\hline
\end{tabular}




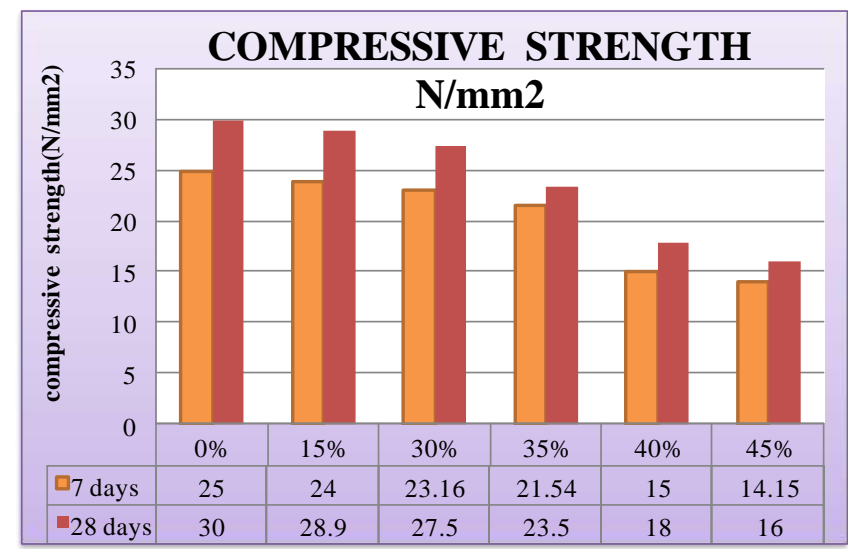

Fig1.2: Comparison of compressive strength test of a0\& a1 to $\mathrm{a} 5 \%$

\subsection{Discussion on Comparison of Strength}

- The compressive strength of concrete made with Ceramic waste gives equal strength to that of conventional concrete mentioned in graph (Figure 4.7).

- The flexural strength of concrete made with ceramic waste gives equal strength to that of conventional concrete mentioned in graph (Figure 4.22)

- The tensile strength of concrete made with ceramic waste gives equal strength to that of conventional concrete mentioned as graph (Figure 4.14)

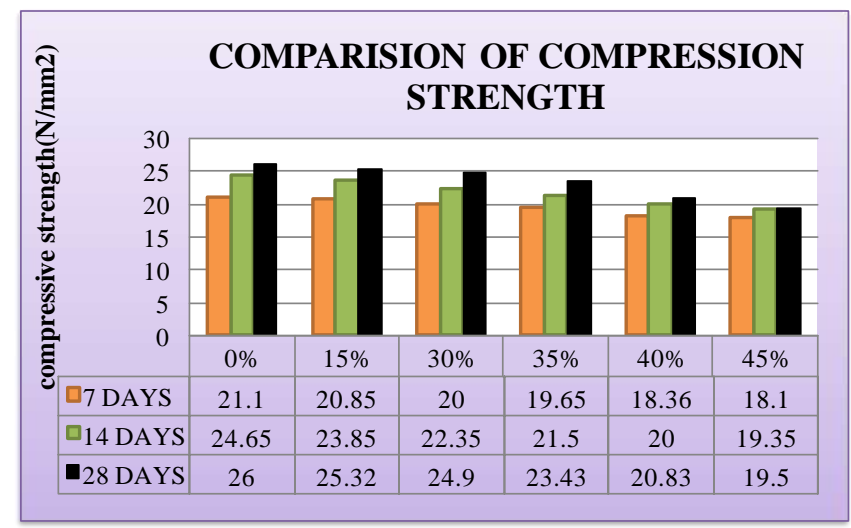

Fig 1.3: Comparison of compressive strength test of A0\&A1 TO A5\%

\section{CONCLUSION}

The study indicates that the barren ceramic can be recycled in concrete without affecting the durability parameter. Analysing the result containing the replacement of ceramic waste powder in concrete gives the following results.

- When the concrete was replaced by $35 \%$ of ceramic powder the compressive strength attained was 23.43 $\mathrm{N} / \mathrm{mm}^{2}$ and the cost decreased up to $25 \%$ in M20 grade.

- The replacement of cement with ceramic waste upto $35 \%$ by weight of cement rises the compressive strength and further replacement of cement with ceramic waste falls the compressive strength.

- Therefore it suits more cost-effective without compromising the concrete strength. It becomes theoretically and economically reasonable and sustainable. It has been concluded that replacement of cement by ceramic wastes in concrete upto $35 \%$ is having good strength.

\section{REFERENCES}

[1] Amitkumar D. Raval, Indrajit N. Patel, (July2013) "Eco-Efficient Concretes: Use Of Ceramic Powder as A Partial Replacement of Cement" ISSN: 2278-3075, Volume-3, Issue-2,

[2] Eva Vejmelková\&TeresaKulovaná, "Application of Waste Ceramics as Active Pozzolana in Concrete Production", IPCSIT vol. 28

[3] İ.B.Topçu and m.canbaz, (2007 )"Utilization of crushed tile as aggregate in concrete", Iranian Journal of Science \&Technology, Transaction B, Engineering, Vol. 31, No. B5, pp. 561-565,

[4] Medina Martinez, M. I. Gerome Romero(2009),"USE OF CERAMIC WASTES IN STRUCTURALS CONCRETES", National Conference on Advances in Materials Recycling and Eco - Energy

[5] M.S. Shetty (2005), "Concrete Technology - Theory and practice".

[6] O.Zimbili, W. Salim, M. Ndambuki (2014 )“AReview on the Usage of Ceramic Wastes inConcrete Production", International Journal of Civil, Structural, Construction and Architectural Engineering Vol: 8, No: 1 ,

[7] Prof. Costas Skidlids,(2011) "Advances in Ceramics -Electric and Magnetic Ceramics, Bio ceramics, Ceramics and Environment", chap24 pg. (533-547). 